\title{
COCOA PRODUCTION PATTERN IN NIGERIA: THE MISSING LINK IN REGIONAL AGRO-ECONOMIC DEVELOPMENT
}

\author{
Olusola Samuel AFOLAYAN * \\ Tai Solarin University of Education, Department of Geography and Environmental Management, College of Social and \\ Management Sciences, Ijebu-Ode, Ogun State, Nigeria, e-mail: afosam84@gmail.com
}

Citation: Afolayan, O.S. (2020). Cocoa Production Pattern in Nigeria: The Missing Link in Regional Agro-Economic Development. Analele Universităţii din Oradea, Seria Geografie, 30(1), 88-96. https://doi.org/10.30892/auog.301110-815

\begin{abstract}
Pre-independent in Nigeria, cocoa was one of the main source of revenue but lost its glory to the discovery, exploration and exploitation of crude oil, especially from the 70s onwards. Despite the rapid growth in its production and positive impact in the nation's economy, cocoa production has been witnessing drastic reduction when compared with percentage of population involving in agriculture since the discovery of crude oil in commercial quantity in Nigeria. This paper reviews the trend pattern of cocoa production and its place in Nigerian economy from pre-1970 up to 2012. It was discovered that most of the cocoa plantations were old and majority of proposed cocoa processing factories were not functioning. The study recommends equilibrium practice of cocoa production and internal processing, establishment of cocoa processing factories through public-private partnership in cocoa producing states.
\end{abstract}

Key words: Cocoa, export, production, processing, trend

* $\quad * \quad * \quad * \quad * \quad *$

\section{INTRODUCTION}

Cocoa is produced by comparatively few countries; all of them tropical, but the product is processed and consumed mainly in temperate countries (Asiedu, 1989). Eclipsed these days by oil as the country's major export, Nigeria still produces 300-350 metric tons of cocoa a year, most destined for consumption abroad - the country exports about $96 \%$ of its cocoa crop. Cocoa (Theobroma cacao) is a major economic tree crop in Nigeria because it provides jobs and income to the farmers, raw materials for industries and foreign exchange for the country. Between 1950 and 1960, cocoa was the highest source of foreign exchange in the country. The discovery of oil in 1970, coupled with other socio-economic factors led to the relegation of cocoa to the second position in terms of foreign exchange earnings for the country. Since then, the oil sector has been at the centre of the Nigerian economy with attendant poverty, unemployment and a weak industrial base.

\footnotetext{
${ }^{*}$ Corresponding Author
} 
Nigeria is the fourth-largest producer of cocoa beans in the world behind Côte d'Ivoire, Ghana and Indonesia. After petroleum, cocoa is the country's most important agricultural ex port product. Fourteen of Nigeria's 36 states grow cocoa of which more than $80 \%$ are from southwest geopolitical zone. Inability of the Nigerian farmers to produce cocoa like Ghana and Côte d'Ivoire are attributed mainly to loss of soil fertility, world price fluctuation, aging plantation, and negligence of agriculture in favour of crude oil by government. Since 70s, crude oil has remained the highest source of foreign exchange earnings while cocoa, a versatile, renewable and sustainable source of revenue is yet to reclaim its lost glory. Also, cocoa production in Nigeria is retarded by declining productivity of the existing old cocoa trees. Cocoa production in Nigeria is undertaken mostly by poor, small scale and low technical farmers that neither use fertilizer nor manure for soil fertility improvement. These farmers therefore face difficulties in setting up new cocoa farms and rehabilitation of old ones. This paper aims at examine cocoa production trend within the period of twenty (25) and factors militating against the production fluctuation over the years.

\section{COCOA PRODUCTION AND NIGERIA ECONOMY}

In the 1960s, the agricultural sector was the most important in terms of contributions to domestic production, employment and foreign exchange earnings. The situation remained almost the same three decades later with the exception that it is no longer the principal foreign exchange earners, a role now being played by oil. Before the discovery of crude oil in Nigeria, major agricultural products such as palm oil, rubber and cocoa (from the South, West and East); groundnut and cotton (from the North) played prominent roles in the growth, development and stability of the nation's economy. Even, Nigeria was once the second leading producer of cocoa in West Africa and palm oil globally. During this period, cocoa ranked the first Nigeria foreign exchange commodity. The issue of unemployment is the product born out of the negligence of the agricultural sector for crude oil exploration and exploitation. In pre-1960s, agriculture was the most important sector of the economy, and accounted for more than $50 \%$ of GDP and $75 \%$ of export earnings. Consequently, with the rapid expansion of the petroleum industry, agricultural development was neglected, and the sector entered a relative decline (Akinwumi, 2013).

Declined agricultural productivity due to oil discovery in Nigeria has drastically reduced the volume of agricultural products and revenue from cash crops over the years. Nigeria's dependence on oil is a disaster to the country's economic growth due to the negligence of nonoil products such as cocoa, cassava, palm oil, among others, that made Nigeria great in the first Republic (Akinwumi, 2013). Thus, between the mid-sixties and the mid-eighties, Nigeria moved from a position of self-sufficiency in basic foodstuffs to one of heavy dependence on imports. Under-investment, a steady drift away from the rural to urban areas, increased consumer preferences for imported foodstuffs (particularly rice and wheat) and outdated farming techniques have kept the level of food production well behind the rate of population growth.

Of non-oil exports, cocoa has been dominant. It accounted for over $50 \%$ of the total export in 1970 s, and over $60 \%$ in 1980 . However, since the 1970 s, its share steadily declined from $49 \%$ in 1989 to $22 \%$ in 1998 (Aigbokhan, 2001). Cocoa was the most important agricultural export crop during 1960-1970, contributing significantly to foreign exchange earning of the country. According to Osuntogun et al., (2007), prior to the 1970s, the policy of government towards agricultural development in general and to cocoa production in particular in Nigeria was one of minimum government interventions. The production increased gradually to 308, 000 metric tonnes in 1970/71. The Structural Adjustment Programme (SAP) policy period introduced liberalization which resulted in improved cocoa pricing at the farm gate and increased output in the short run. Also, Osuntogun et al., (2007) attributed the consistency in economic down turn and decline aggregate cocoa output in Nigeria to the introduction of SAP programme in 1986. In addition, Awe (2013) blames the reduction in cocoa production on military intervention in Nigeria politics in 1986. This negatively affects the cooperatives which 
virtually collapsed after the abolition of the commodity boards. By 1999, the production level had declined to 170,000 metric tonnes.

In terms of export earning according to Aigbokhan (2001), agricultural export accounted for $81 \%$ of total export in $1955-59,80 \%$ in 1960-64 and 57\% in 1965-69. In terms of contribution to GDP, agriculture was the leading sector in the 1950s and 1960s, agricultural output accounted for 63 percent of GDP, and in 1965-69 for 54 percent (Aigbokhan, 2001). In 1970-74, it declined to 33 percent, a period which marked the watershed in Nigeria's economic history through the 1973/74 crude oil price shocks. However, from 1970, the decline became very dramatic and this coincided with the prominence of crude oil as the country's main export commodity. In 1970-74, agriculture accounted for $26 \%$ of the total exports, thereafter it accounted for less than $10 \%$, being $5.7 \%$ in $1975-79,2.7$ and $5.6 \%$ in 1980-84 respectively. In 1990-93, it's nose-dived to its lowest at 1.8\%, before some recovery in 1994-98 (Aigbokhan, 2001). International Cocoa Organization (2010) reported that, of the global production, Africa production of cocoa beans has declined from $71.8 \%$ in 2007/2008 to 68\% in 2009/2010 while Americas, Asia and Oceania have increased from $12.5 \%$ and $15.8 \%$ to $14.4 \%$ and $17.5 \%$ respectively. The maximum values of cocoa beans exported from Nigeria increased over the period covered from $\$ 309,781,000$ in pre-1970 to $\$ 503,666,000$ in $2000-2009$ (FAO, 2011). Though, production and exportation might varied and fluctuated over the years but exchange earning (\$) increased (table 1). Also, the ministry of trade and industry reported that Nigeria made 1.3billion from cocoa export (Agribusiness, 2017).

Table 1. Cocoa Beans Net Production Value (1970-2009)

Source: Food and Agricultural Organization (2011)

\begin{tabular}{|c|c|c|}
\hline Year & Value & Change (\%) \\
\hline Pre-1970 & $\$ 309,781,000$ & -47.78 \\
\hline $1979-1983$ & $\$ 161,744,000$ & 37.69 \\
\hline $1984-1999$ & $\$ 259,608,560$ & 48.45 \\
\hline $2000-2009$ & $\$ 503,666,000$ & \\
\hline
\end{tabular}

Despite the absolute paradigm shift by the government from agriculture into the crude oil, cocoa still remain the second foreign exchange earning in Nigeria. In Nigeria, cocoa is a major export crop with revenue of at least 34 billion derived annually from the export of cocoa beans alone, besides revenue from cocoa by-products like butter, cake, liquor and powder (Akinwale, 2006; Ibiremo et al., 2011).

\section{HISTORY OF COCOA PRODUCTION IN NIGERIA}

Since its discovery in the $18^{\text {th }}$ century at the Amazon basin, cocoa cultivation has spread to other tropical areas of south and central, and indeed West Africa, which became the major producer from the mid-1960s (Opeke, 1978). According to Eduardo and Philippe (2013), dominance in world cocoa production shifted from America to Africa in the second half of the nineteenth century and remains so to date. Cocoa was introduced to West Africa from Brazil (South America) precisely from Fernando Po into Nigeria in 1874 and Ghana in 1879 by one Squiss Bamengo, a chief of the Niger Delta (Adegeye, 1996). West Africa has been the centre of cocoa cultivation for many decades, as two-thirds of the world's cocoa is produced in West Africa (Hartemink, 2005). West Africa is a major producer accounting of approximately $70 \%$ of global production which fluctuates annually with climatic variations (Abayomi, 2017). Currently, according to International Cocoa Organization (2012) the main producers of cocoa are Cote D'Ivoire, Ghana, Indonesia and Nigeria. Nigeria remains the third largest producer of cocoa and sixth globally. Before the emergence of black gold (crude oil) in Nigeria, cocoa was the major leading cash and export crop in Nigeria especially in southern part of Nigeria. Cocoa was first planted in the Delta region and then spread northward to its suitable cocoa belt of 
Western Nigeria. Cocoa was first planted in the Western Region in 1890 (Oyekale et al., 2009). It rapidly gained prominence in Nigeria to the extent that Nigeria happened to be the second largest producer globally by 1965 . Before the emergence of black gold (crude oil) in Nigeria, cocoa was the major leading cash and export crop especially in the southern part of Nigeria. Nearly all Southwest States in Nigeria except Lagos involve in cocoa production. The top growing States Ondo, Ogun, Osun Oyo and Ekiti account for about $60 \%$ of the cocoa produ ction and make up at least $30 \%$ of the total cocoa export in Nigeria. Others are Cross River, Edo, Abia, Kwara, Kogi, Adamawa, and Akwa Ibom. But Nigerian Bureau of Statistic (2013) identified eighteen cocoa producing States in Nigeria. Therefore in addition to the aforementioned State, others are Taraba, Delta, Lagos, Bayelsa, River and Imo States (table 2).

Table 2. Estimated Area (000) and Production (000 mt) of cocoa in Nigeria Source: National Bureau of Statistics, 2013

\begin{tabular}{|c|c|c|c|c|c|}
\hline & & \multicolumn{2}{|c|}{$2011 / 12$} & \multicolumn{2}{c|}{$2010 / 11$} \\
\hline S/N & State & Area & Production & Area & Production \\
\hline 1 & Ondo & 321.97 & 92.22 & 320.19 & 91.99 \\
\hline 2 & Cross River & 327.91 & 69.42 & 310.99 & 71.45 \\
\hline 3 & Osun & 251.3 & 74.1 & 237.06 & 71.1 \\
\hline 4 & Ekiti & 98.15 & 36.46 & 97.07 & 37.97 \\
\hline 5 & Oyo & 109.03 & 36.06 & 107.75 & 33.57 \\
\hline 6 & Edo & 104.77 & 23.68 & 105.28 & 27.36 \\
\hline 7 & Ogun & 92.76 & 19.9 & 89.84 & 19.88 \\
\hline 8 & Taraba & 10.53 & 4.89 & 9.78 & 4.32 \\
\hline 9 & Delta & 11.52 & 3.93 & 10.69 & 3.81 \\
\hline 10 & Abia & 14.49 & 3.34 & 13.46 & 3.3 \\
\hline 11 & Akwa-Ibom & 5.35 & 1.25 & 6.82 & 2.25 \\
\hline 12 & Adamawa & 5.34 & 1.65 & 5.33 & 1.66 \\
\hline 13 & Kwara & 5.14 & 1.43 & 4.77 & 1.41 \\
\hline 14 & Kogi & 3.84 & 1.06 & 3.56 & 1.05 \\
\hline 15 & Lagos & 0.97 & 0.2 & 0.9 & 0.2 \\
\hline 16 & Bayelsa & 0.32 & 0.09 & 0.3 & 0.09 \\
\hline 17 & Rivers & 0.18 & 0.3 & 0.16 & 0.05 \\
\hline 18 & Imo & 0.04 & 0.01 & 0.04 & 0.01 \\
\hline & National & $1,363.60$ & 370.01 & $1,324.00$ & 371.47 \\
\hline
\end{tabular}

Table 2 show that cocoa is cultivated in 18 States on a total land area of $1,363.60$ hectares in Nigeria. Cross River State cultivated the largest land area with 327.91 hectares followed by Ondo State with 321.97 hectares. The least cultivated land areas were 0.04 and 0.18 hectares by Imo and Rivers State respectively. The total production by the 18 States were 370.01 metric tonnes, with Ondo State contributing the highest with 92.22 metric tonnes, equivalent to $25 \%$ of the total production followed by Osun State with 74.10 metric tonnes per annum. The least production was 0.01 metric tonnes by Imo State. Adegeye (1996) states that over $50 \%$ of the total quantity of cocoa produced for export or utilized locally per annum are from Ondo State. Even within Ondo State, cocoa production is not equally produced among the existing district (North, Central and South). In Ondo State, Idanre, Ondo West and Akure South Local Governments are leading producers from 2005-2007.

Soils in South-Western Nigeria had been classified according to their suitability for cocoa into four categories, namely: good cocoa soils, fairly good cocoa soils, poor cocoa soils and very poor cocoa soils (Ibiremo et al., 2010). A previous survey of cocoa soils of Southwest Nigeria also indicated that $62 \%$ cocoa in the area was planted on good and fairly good soils while $38 \%$ of the cocoa were planted on poor and very poor soils categories. Cocoa production is geographically restricted mainly to the southern, western and eastern parts of the 
country (figure 1). All South Western States in Nigeria except Lagos involved in cocoa production in commercial quantity. Other cocoa producing states in Nigeria apart from southwestern states are, Cross River, Edo, Delta, Taraba, Abia, Kwara, Kogi, Adamawa, and Akwa Ibom States. In Ondo State which is the major producer, production varies. Idanre, Ondo West and Akure South Local Governments are the leading producers of cocoa over the years. According to National Cocoa Survey (2005), Ondo State ranked first among the fourteen cocoa producing States in Nigeria (Aikpokpodion, 2010). Over 50\% of the total quantity of cocoa produced for export or utilized locally per annum always comes from Ondo State (Ajayi et al., 2010). About four major tree crops (cocoa, rubber, palm tree and cashew) produced in Ondo State, cocoa alone accounts for $80.69 \%$ with annual increases of $6.44 \%$ over twelve years (2000-2011) of observation (Afolayan and Ajibade, 2012).

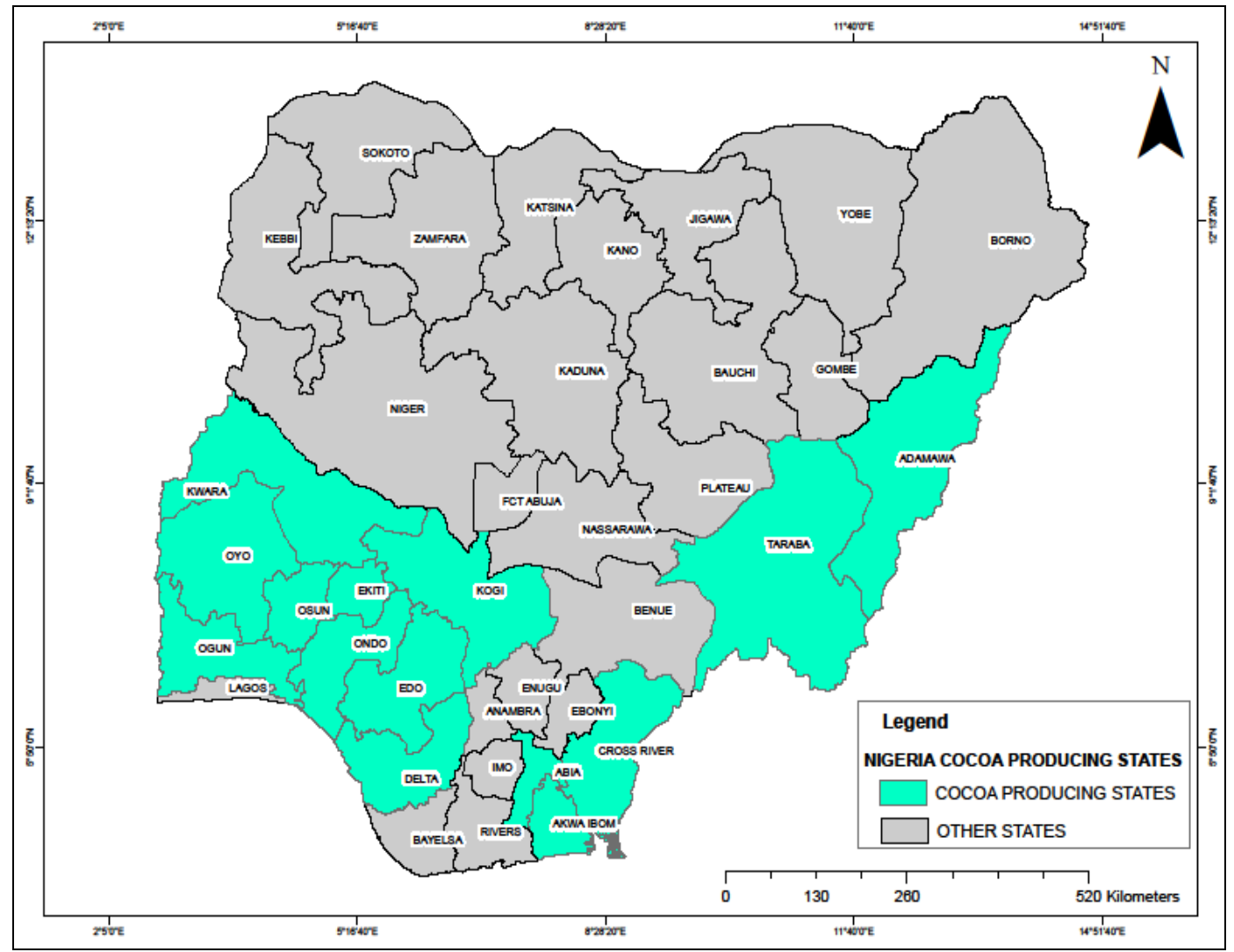

Figure 1. Cocoa Producing States in Nigeria

Source: NCDC (2010) and Afolayan (2016)

Observation on cocoa production data from table 3 calls for serious attention. In summary, it indicates that a remarkable change above 50\% of cocoa production occurred from 1971 to 2010. Also in 1988, cocoa output increased from 100,000 metric tonnes in 1986 to 230,000 tonnes, 203, 000 tonnes to 323,000 tonnes from1994 to 1995 and 225,000 tonnes (1999) to 338,000 tonnes (2000). The percentage for the three years was approximately $130 \%, 59.1 \%$ and $50.2 \%$ positive change above the previous years (figure 1). The situation of cocoa production and exportation in Nigeria is calling for attention due to the increase in the rate of importation. Production and exportation pattern were decreased at the same rate from 1970-1980. 
Table 3. Cocoa Production and Exportation in Nigeria

Source: Modified from NBS (2013), Taiwo et al. (2016), www.statista.com (2019)

\begin{tabular}{|c|c|c|c|c|c|}
\hline \multicolumn{3}{|c|}{ Production and Export in Tonnes } & \multicolumn{3}{|c|}{ Production and Export in Tonnes } \\
\hline Year & Output & Export & Year & Output & Export \\
\hline 1970 & 305,000 & 302,000 & 1994 & 203,000 & 147,897 \\
\hline 1971 & 257,000 & 254,000 & 1995 & 323,000 & 138,981 \\
\hline 1972 & 241,000 & 241,000 & 1996 & 325,000 & 182,065 \\
\hline 1973 & 215,000 & 212,000 & 1997 & 318,000 & 147,075 \\
\hline 1974 & 214,000 & 212,000 & 1998 & 370,000 & 135,041 \\
\hline 1975 & 216,000 & 215,000 & 1999 & 225,000 & 208,617 \\
\hline 1976 & 181,000 & 179,000 & 2000 & 338,000 & 144,821 \\
\hline 1977 & 193,000 & 192,000 & 2001 & 340,000 & 184,122 \\
\hline 1978 & 157,000 & 152,000 & 2002 & 362,000 & 191,992 \\
\hline 1979 & 151,000 & 150,000 & 2003 & 385,000 & 385,000 \\
\hline 1980 & 153,000 & 150,788 & 2004 & 412,000 & 412,000 \\
\hline 1981 & 174,000 & 213,551 & 2005 & 441,000 & 441,000 \\
\hline 1982 & 156,000 & 154,577 & 2006 & 485,000 & 485,000 \\
\hline 1983 & 140,000 & 228,220 & 2007 & 500,000 & 500,000 \\
\hline 1984 & 140,000 & 151,183 & 2008 & 502,000 & 502,000 \\
\hline 1985 & 160,000 & 116,161 & 2009 & 513,000 & 513,000 \\
\hline 1986 & 148,000 & 174,600 & 2010 & 525,000 & 525,000 \\
\hline 1987 & 100,000 & 117,070 & 2011 & 370,010 & N/A \\
\hline 1988 & 230,000 & 220,322 & 2012 & 371,470 & N/A \\
\hline 1989 & 256,000 & 148,982 & 2013 & 238,000 & N/A \\
\hline 1990 & 244,000 & 153,520 & 2014 & 248,000 & N/A \\
\hline 1991 & 268,000 & 160,395 & 2015 & 200,000 & N/A \\
\hline 1992 & 292,000 & 110,749 & 2016 & 230,000 & N/A \\
\hline 1993 & 306,000 & 160,420 & 2017 & 240,000 & N/A \\
\hline
\end{tabular}

Table 3 shows that from 2003 to $2010,100 \%$ of the nation cocoa output ended up in the foreign country. This implies that cocoa production in Nigeria servicing the processing and other companies in developed countries at the detriment of Nigeria economy. This laid the foundation for the unemployment in Nigeria and setback in agro-economy sector. A living example is Multitrex Integrated Food Plc. in Ogun State, Nigeria. Today, most of the processing industries are folding-up like Multi-trex while existing ones are not functioning and new ones are not coming on board due to government policies on agricultural products and trade agreement with foreign countries. Declining in cocoa production pattern may be attributed to the absence of cocoa processing industries while the wide gap between 1980-1989 could be the impact of the local cocoa processing industries establishment like Cocoa Industries Limited, Ikeja, Lagos, Cocoa Products (Ile-Oluji) Limited and Stanmark Cocoa Processing Co. Ltd., Ondo State, Multi Trex Integrated Food Plc., Ogun States and others (figure 2).

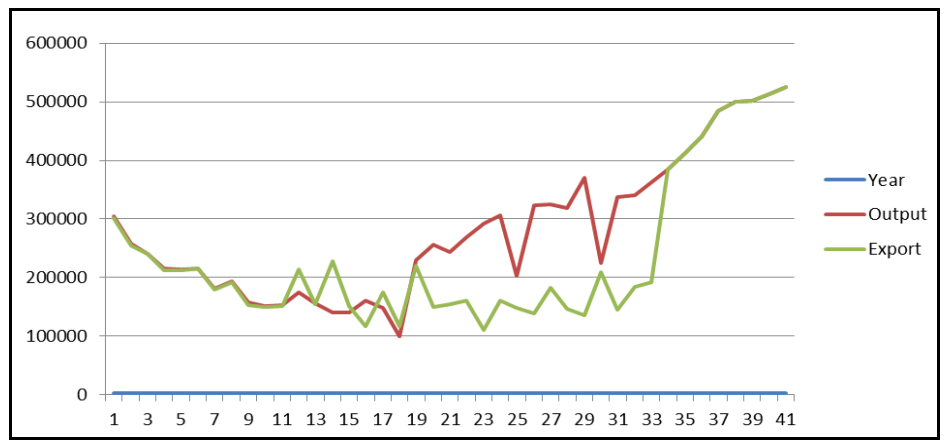

Figure 2. Cocoa Production Trend Pattern in Nigeria Source: Author's Analysis (2018) 
Impart of research institutes such as Cocoa Research Institute of Nigeria, Ibadan established in 1964 as well as the output of the introduced hybrid cocoa species reflects on annual production from 1988 onward.

\section{MISSING LINK IN NIGERIA LOCAL COCOA PROCESSING INDUSTRIES}

Varying opinions are put forward for the problems militating against the rapid drop in the quantity of cash crop production in Nigeria. Economy survival of Africa countries, particularly Nigeria had been on cash crop production dated pre-colonial era till the first decade after independence. Agriculture used to be the mainstay of Nigerian economy, providing $65 \%$ of Gross Domestic Product (GDP) in the 1960s (Kayode, 2010). But according to Oduwole (2001), its contribution has dropped in recent times to about 26\%. Problems militating against cocoa production in Nigeria are climate change, aging of plantation, soil nutrient degradation (natural) and negligence of agricultural sector in favour of oil exploitation, internal and external price fluctuation, and excess exportation due to shortage of cocoa processing factories in Nigeria (human). Apart from these, production and marketing of cocoa has witnessed series of difficulties since 1970s. The price of agricultural products in developing countries is not always stable. Even the government of the country does not has capacity to determine price because of weakness in the area of insufficient local processing industries, absence of cocoa boards, government policy on agricultural products, bi-lateral agreement with the foreign nations and other. Apart from the external factors, cocoa price differs seasonally among the cocoa producing states in Nigeria.

According to Afolayan and Ajibade (2012), Nigeria exports about $86 \%$ of raw cocoa bean into the countries of the north on annual basis due to incapability of the available factories to meet up with the global demand. Similarly, Proshare Economy (2017) emphasized that in Nigeria; about $80 \%$ cocoa produced is exported as cocoa beans while the other $20 \%$ is processed into powder, butter, cake and liquor before being exported. Nigeria is yet to fully capitalize on cocoa production, as most of the beans are sold unprocessed. The study also identified eight cocoa processing factories in Nigeria with combined installed capacity of 150,000 metric tons but only four of them are functional with a combined total volume of 50,000 metric tons per annum. Shortage of cocoa processing factories also added to the problem of cocoa production and marketing in Nigeria. According to experts' statistics, presently, there are about 17 cocoa processing companies in Nigeria; only 9 are functional (Akinfolarin et al., 2012). The rest have either not been completed, closed down or did not come on board at all. Functional cocoa processing factories in Ondo State, the leading producer of cocoa in Nigeria process about 63,000 metric tonnes annually. The newly resuscitated Osun State Cocoa Processing Industry in Ede, Osun State, Nigeria was inaugurated on October 17, 1982, had stopped production in 2001 due to obsolete equipment and management issues (This Day, 2017).

Table 4. Nigeria Cocoa Processing Industrial Capacity

Source: Author Data Analysis (2018)

\begin{tabular}{|c|l|l|c|c|}
\hline S/N & Industry & Location & Year & Capacity \\
\hline 1 & Cocoa Products Ltd & Ile-Oluji, Ondo State & 1984 & 30,000 \\
\hline 2 & Cooperative Cocoa Products Ltd & Akure, Ondo State & 1992 & 18,000 \\
\hline 3 & Stanmark Cocoa Processing Company Ltd & Ondo, Ondo State & 1992 & 15,000 \\
\hline 4 & Cocoa Industries Ltd & Ikeja, Lagos State & 1964 & 30,000 \\
\hline 5 & Multi-Trex Ltd & Warawa, Ogun State & 2006 & 12,000 \\
\hline 6 & Osun State Cocoa Processing Industry & Ede, Osun State & 1982 & n.a \\
\hline 7 & FTN Cocoa Processor Plc & Ibadan, Oyo State & 1991 & n.a \\
\hline 8 & Cadbury Nigeria Plc Cocoa Processing & Akure, Ondo State & & \\
\hline & & & & 105,000 \\
\hline
\end{tabular}


Summary of local cocoa processing capacity in Nigeria is approximately 105,000 metric tonnes while the annual production above 370,000 metric tonnes (table 2). In 2011 and 2012, Nigeria production of cocoa in amounts to $370,000 / 371,000$ metric tonnes respectively (Afolayan, 2016). Reports on annual production of cocoa for Nigeria are conflicting. Annual cocoa yields for Nigeria are generally estimated at an average of between 300 to 350,000 metric tons. With regards to their processing capacity Stanmack Cocoa Processing Company Limited, Ondo (15,000), Cocoa Product, Ile-Oluji $(30,000)$ and Cooperative Cocoa Products Ltd, Akure $(10,000)$ (table 4). Effective and efficient functioning of the aforementioned factories would definitely generate thousands of employment either directly or indirectly via multiplier effect. The erstwhile foremost cocoa factory in Nigeria rated as the first in Africa-Cocoa Industries Limited; Ikeja had about 19,000 workers when it was at the peak of production. The processing companies also have many challenges such as irregular power supply, high cost of cocoa bean, inefficient, inadequate working capital as well as obstructive government policies.

\section{CONCLUSIONS}

The trend pattern of cocoa production and exportation in Nigeria has been fluctuating since 1970 while generated revenue has been increasing. Exportation is geometrically increasing while local processing is gradually dwindling; the basis for more attention on local processing industries as agro-economy instrument of regional development. To drastically diversify the country economy from mono-economy, the country policies on export agricultural produces needs to be reviewed in favour of local processing. That is equilibrium on cocoa production, internal processing and exportation of semi-finished or finished product should be the main focus of the country rather than absolute concentration on the rate of production alone. Emphases should be laid on the local processing industries in all cocoa producing State across the countries through Public Private Partnership in order to strengthen the stability of the industries rather than one man business. Also, the processes for the revitalization of the liquidated Cocoa Board need to be reviewed. The study also recommends the use of cocoa production as a mean of regional economic development because of its multiplier effect in anticipation of unemployment rate reduction and nation gross domestic product improvement.

\section{REFERENCES}

Abayomi, A. (2017). Cocoa Production in Nigeria: A Literature Review. Analysis, Food and Agribusiness (accessed from www.cpparesearch.org, 11/06/19).

Adegeye, A.J. (1996). Production and marketing of cocoa in Nigeria, problem and solution. Proceedings of National seminal on revolutionalising Nigeria's cocoa industry, Ibadan, Nigeria.

Afolayan, O.S. (2016). Comparative Analysis of Nutrient Status in Indigenous and Hybrid Cocoa Farms in Tropical High Forest Agroecological Zone of Nigeria. An Unpublished Ph.D Thesis, Department of Geography, University of Ilorin, Nigeria.

Afolayan, O.S., \& Ajibade, L. T. (2012). Temporal variation in perennial cash crops production in Ondo State, Nigeria. Asian Journal of Natural \& Applied Sciences, 1(3), 72-78.

Agribusiness (2017). Africa agriculture status report: The business of smallholder agriculture in Sub-Saharan Africa.

Aigbokhan, B.E. (2001). Resuscitating agricultural production (cocoa, cotton, groundnuts, palm oil, rubber, etc) for exports. In $10^{\text {th }}$ Annual Conference of Zonal Research Unit of The Central Bank of Nigeria, held in Owerri.

Aikpokpodion, P.E. (2010). Nutrient Dynamics in Cocoa Soils, Leaf and Beans in Ondo State, Nigeria. Journal of Agricultural Science, 1(1), 1-9.

Ajayi, I. R., Afolabi, M. O., Ogunbodede, E. F., \& Sunday, A. G. (2010). Modeling rainfall as a constraining factor for Cocoa yield in Ondo State. American Journal of Scientific and Industrial Research, 1(2), 127-134.

Akinfolarin, A. O., Oseni, J. O., \& Imoudu, P. B. (2012). Operational Activities of Cocoa Export Processing Factories in Ondo State, Nigeria. Journal of Agricultural Sciences, 3(1), 1-13.

Akinwale, O. (2006). Prospects and challenges in local production of cocoa as raw materials in Nigeria. Cocoa Mirror, 1, 9-11.

Akinwumi, A. (2013). Nigeria's Dependence on Oil, A Disaster. Punch Newspaper, $22^{\text {nd }}$ May p. 18.

Asiedu, J.J. (1989). Processing Tropical Crops. A Technological Approach, Macmillan, London, p. 265.

Awe (2012). Nigeria Exports Cocoa to Import Chocolates is Sad. Punch Newspaper, $30^{\text {th }}$ January. 
Eduardo, S., \& Philippe, L. (2013). Successional Cocoa Agroforests of the Amazon-Orinoco-Guiana Shield. Forests, Trees and Livelihoods, 22 (1), 51-59

FAO. (2011). Production Database for Nigeria.

Hartemink, A.E. (2005). Nutrient Stocks, Nutrient Cycling and Soil Changes in Cocoa Ecosystems: A Review. Advance in Agronomy, 6, 227-253.

Ibiremo, O. S., Daniel, M. A., Iremiren, G. O., \& Fagbola, O. (2011). Soil fertility evaluation for cocoa production in Southeastern Adamawa State, Nigeria. World Journal of Agricultural Sciences, 7(2), 218-223.

Ibiremo, O. S., Ipinmoroti, R. R., Ogunlade, M. O., Daniel, M. A., \& Iremiren, G. O. (2010). Assessment of soil fertility for cocoa production in Kwara State: Southern Guinea Savanna Zone of Nigeria. Journal of Agricultural Sciences, $1(1), 11-18$

Osuntogun, D. A., \& Oluwasola, O. (2007). Effects of market deregulation on cocoa (Theobroma cacao) production in Southwest Nigeria. African Journal of Agricultural Research, 2(9), 429-434.

International Cocoa Organization's (2010). Quarterly Bulletin of Cocoa Statistics.

International Cocoa Organization's (2012). Quarterly Bulletin of Cocoa Statistics.

National Bureau of Statistic (2013). National Survey on Agricultural Exportable Commodities Report.

Oduwole, O.O. (2001). Sustainable cocoa production in Nigeria: Farmers perception of technology characteristics and socio economic factors in adoption decision. In Proceedings of the 13 th International Cocoa Research Conference (pp. 1147-1152).

Kayode, O.A. (2010). Different Agro-Ecological Zones in Nigeria. World Journal of Agricultural Sciences, 6(5), 609-614.

Opeke, O. (1978). Tropical Tree Crops. Longman, Ibadan.

Oyekale, A.S., Bolaji, M.B., \& Olowa, O.W. (2009). The effects of climate change on cocoa production and vulnerability assessment in Nigeria. Agricultural Journal, 4(2), 77-85.

Proshare Economy (2017). Reviving the Cocoa Industry in Nigeria (Accessed from www.proshareng.com, 11/06/19)

This Day (2017). Nigeria: Osun Cocoa Industry Now Processes 20,000 Tonnes Daily (Accessed from www.allafrica.com on $04 / 06 / 18$ )

Submitted:

May 24, 2019
Revised:

December 27, 2019
Accepted and published online

June 04, 2020 